\title{
МОДЕЛЬ ПРЕДСТАВЛЕННЯ ЕКСПЕРТНИХ ЗНАНЬ В ІНТЕЛЕКТУАЛЬНІЙ СИСТЕМІ ДІАГНОСТИКИ ЗАХВОРЮВАНЬ
}

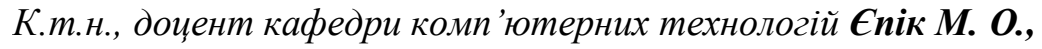 \\ Украӥна, Вінницяя, Донецьький національний університет імені Василя Стуса
}

DOI: https://doi.org/10.31435/rsglobal_wos/31012019/6305

\section{ARTICLE INFO}

Received: 19 November 2018

Accepted: 26 January 2019

Published: 31 January 2019

\section{KEYWORDS}

expert knowledge, intellectual system, fuzzy logic, rule-based model, linguistic variable \begin{abstract}
In this article the model of representation of expert knowledge is offered in the intellectual system of diagnostics of diseases. The problem of representation of knowledge is considered. The use of rule-based model is reasonable. Determination over of linguistic variable is brought. Description of knowledge of the system is presented as linguistic variables. A fragment over of description of linguistic variables of the system is brought. The base of fuzzy rules of the system is described. Description of form of fuzzy rules is presented. Examples of external and internal representation of knowledge are made.
\end{abstract}

Citation: Спік M. O. (2019) Model Predstavlennia Ekspertnykh Znan v Intelektualnii Systemi Diahnostyky Zakhvoriuvan. International Academy Journal Web of Scholar. 1(31), Vol.1. doi: 10.31435/rsglobal_wos/31012019/6305

Copyright: (C) 2019 Спік М. O. This is an open-access article distributed under the terms of the Creative Commons Attribution License (CC BY). The use, distribution or reproduction in other forums is permitted, provided the original author(s) or licensor are credited and that the original publication in this journal is cited, in accordance with accepted academic practice. No use, distribution or reproduction is permitted which does not comply with these terms.

Вступ. Розробка інтелектуальних інформаційних систем, які грунтовані на знаннях, один з напрямків штучного інтелекту. При побудові таких систем пріоритетним $є$ виявлення знань висококваліфікованих експертів, їх застосування і дослідження для розв'язання складних практичних задач. Знання, що накопичені експертами, представляються у вигляді конкретних правил розв'язання поставленої задачі. Розробка інтелектуальних інформаційних систем пов'язана 3 імітацією неструктурованих і слабкоструктурованих проблем. Окрім цього, дослідження в цієї області пов'язані 3 розробкою моделей витягання, представлення i структуризації знань.

Результати досліджень. Однією 3 найбільш важливих проблем, що характерні для систем, які грунтовані на знаннях, є проблема представлення знань. Це пояснюється тим, що форма представлення знань робить істотний вплив на характеристики і властивості системи. При проектуванні моделі представлення знань слід враховувати такі чинники як однорідність представлення і простота розуміння. Однорідне представлення призводить до спрощення механізму керування логічним висновком і спрощенню керування знаннями. Представлення знань має бути зрозумілим для експертів і користувачів системи. Інакше утруднюється придбання знань i їх оцінка. Проте виконати цю вимогу як для простих, так i для складних систем досить складно [1].

Продукційна модель представлення знань є досить ефективною для інтелектуальної системи, що розробляється. Вона працює 3 простими складовими знання - фактами i 
правилами, і спрямована на розв'язання простих, однорідних задач. Проте слід зазначити що недоліком даної моделі $є$ неможливість ефективно описати правила з виключеннями.

Інтелектуальна система діагностики захворювань $\epsilon$ системою нечітких продукцій, що використовує знання у вигляді лінгвістичних змінних. Лінгвістична змінна (ЛЗ) - змінна, яка набуває своїх значень з множини лінгвістичних термів і характеризується параметрами [2]:

$$
<X, T(X), E, G, M>,
$$

де $X$ - назва лінгвістичної змінної; $T(X)=\{\aleph\}$ - множина назв (терм-множина змінної $X$ ), тобто множина назв лінгвістичних значень $X$, кожне з яких - нечітка змінна $X$ зі значеннями 3 універсальної множини $E ; \boldsymbol{\aleph}$ - значення лінгвістичної змінної; $E=\{e\}$ - універсальна множина; $G$ - синтаксичне правило, що породжує назви $\aleph$ значень змінної Х; $M$ - семантичне правило, яке ставить у відповідність кожному значенню $\aleph$ лінгвістичної змінної $X$ iї сенс $M(\aleph)$, тобто нечітка множина обмежень на множині $E$. [2]:

Представимо лінгвістичну змінну не в загальному вигляді (1), а в частковому вигляді

$$
<X, T(X), E,\{R(x, e), \forall x \in T(X)\}>\text {. }
$$

У вираженні (2) опущений запис синтаксичного правила $G$ і замість семантичного правила $M$ записані в явному вигляді нечіткі обмеження для усіх значень ЛЗ.

Наприклад, введемо ЛЗ для позначення температури тіла людини:

$<$ Температура_тіла=\{низька, знижена, нормальна, субфебрильна, помірно підвищена лихоманка, висока лихоманка, надмірно висока лихоманка, гіперпіретична лихоманка $\}$, $E=[20.0 ; 42.0], \quad\{R($ низька, $e), \quad R$ (знижена, $e), \quad R$ (нормальна, $e), \quad R$ (субфебрильна, $e), \quad R($ помірно підвищена лихоманка, $e$ ), $R$ (висока лихоманка, $e), \quad R$ (надмірно висока лихоманка, $e$ ), $R($ гіперпіретична лихоманка,е) $\}>$.

Рівняння призначення для лінгвістичної змінної відображає, що лінгвістичною змінною $X$ призначається значення $x \in T(X)$, де $x \in$ термом, а по суті це назва нечіткої змінної 3 урахуванням обмеження $R(x, e)$ :

$$
X=x: R(x, e) .
$$

Рівняння сенсу для ЛЗ грає таку ж роль, як і сумісність для нечіткої змінної:

$$
M(x)=R(x, e) .
$$

База знань інтелектуальної системи діагностики захворювань містить: базу лінгвістичних змінних і базу нечітких правил.

База лінгвістичних змінних спирається на їх традиційне представлення у пам'яті [2]. Формальне визначення ЛЗ - задача, яка вирішується на підставі даних попереднього словесного опису, який представлений вербальною моделлю.

Лінгвістичні змінні для усіх блоків правил бази нечітких правил, окрім блоків «Первинні скарги пацієнта» i «Загальний огляд пацієнта», об’ єднуються в групи: скарги, огляд, пальпація, перкусія, аускультація [3].

Приведемо фрагмент опису лінгвістичних змінних системи (блок «Загальний огляд пацієнта») і вкажемо множину їх лінгвістичних термів. Загальний огляд пацієнта включає визначення: загального стану пацієнта, його свідомості, положення пацієнта, статури, температури тіла, вираження і особливостей обличчя, стану шкірних покривів і придатків шкіри, висипань на шкірі, судинних змін, видимих пухлин, вологості і тургора шкіри, стану волосся, стану нігтів, стану зіва, стану склер, стану підшкірно-жирової клітковини, набряків, стану лімфатичних вузлів, стану м'язів, стану кісток і стану суглобів.

Нехай $\Omega_{2}^{*}-$ множина лінгвістичних змінних блоку «Загальний огляд пацієнта»:

Загальний_стан_паиієнта $=\{$ задовільний, середньої тяжкості, важкий $\}$;

Свідомість $=\{$ ясна, сплутана $\}$;

Положення_пацієнта $a=\{$ активне, пасивне, вимушене $\}$;

Статура_конституиіональний_mип $=\{$ нормостеник, гиперстеник, астеник $\}$; 
3picm $=\{$ низький, нижче середнього, середній, вище середнього, високий $\}$;

Maca_miла $=\{$ значно нижче норми, нижче норми, нормальна, вище норми, значно вище норми $\}$; Постава $=\{$ пряма, сутула $\}$;

$X о д a=\{$ атактична, спастична, геміпаретична, параспастична, гіпокінетична, спастикоатактична $;$

Tемпература_тіла=\{низька, знижена, нормальна, субфебрильна, помірно підвищена лихоманка, висока лихоманка, надмірно висока лихоманка, гіперпіретична лихоманка $\}$;

Вираження_обличчя=\{спокійне, байдуже, маскоподібне, тужливе, страждальне, збуджене, стомлене ;

Особливості_обличчя $=\{$ обличчя Корвізара, facies febris, facies nephritica, facies mitralis, ficies Hyppocratica, facies Basedovica\};

Шкірні_покриви_Придатки_икіри_колір $=\{$ блідо-рожевий, смуглявий, червоний, жовтяничний, синюшний, блідий, землистий $\}$;

Пігментація_наявність $=\{\epsilon$, немає $\}$;

Пігментаичія_локалізація $=\{$ одинична, множинна $\}$;

Депігментачія(лейкодерма)_наявність $=\{\epsilon$, немає $\}$;

Депігментація(лейкодерма)_локалізація $=\{$ одинична, множинна $\}$;

Висипання_форма_висипу $=\{$ розеоли, папули, пустули, везикули, екзема, плями, булли, «гарячкові» висипання-herpes $\}$;

Висипання_локалізаиія $=\{$ кільцьова, лінійна, група $\}$;

Судинні_зміни $=\{$ телеангіоектазії, «судинні зірочки» $\}$;

Судинні_зміни_локалізація $=\{$ одинична, множинна $\}$;

Крововиливи_характер $=\{$ синяки, петехії, гематоми $\}$;

Видимі_пухлини $=\{$ міома, ангіома, атерома $\}$;

Тургор_шкіри $=\{$ нормальний, нижче норми, знижений $\}$;

Вологість_икіри $=\{$ знижена, помірна, підвищена $\}$;

Шкіряні_висипання (екзантеми)=\{макула, пляма, папули, бляшки, вугри, пухирі, везикули, булли, пустули, пурпура, петехії, екхімози $\}$;

Шкіра_вторинне_ураження $=\{$ екскоріації, лихеніфікація, лусочки, кірки, ерозії, виразки, тріщини, атрофія\};

Волосся_mun=\{сухе, нормальне, жирне, комбіноване $\}$;

Волосся_випадання $=\{\epsilon$, немає $\}$;

Hігті_зміна_форми=\{«барабанні палички», ложкоподібні, оніхолізис, симптом наперстка, лінії Бо, жовті\};

Hiгmi_зміна_кольору $=\{$ нігті Тері, блакитні, нігті Линдсея, лінії Мюрке, лінії Миза, темні подовжні смужки, подовжні борозенки, геморагії у вигляді заноз, телеангіоектазії\};

Видимі_слизові_оболонки_колір $=\{$ рожевий, блідий, жовтяничний, червоний, синюшний $\}$;

Видимі_слизові_оболонки_вологість $=\{$ знижена, помірна, підвищена $\}$;

Видимі_слизові_оболонки_паталогічні_зміни $=\{$ наліт, афта, виразки, елементи висипу, кровоточивість ясен $\}$;

Зів_забарвлення $=\{$ норма, гіперемійований, «палаючий зів» $\}$;

Мигдалини_забарвлення $=\{$ норма, гіперемійовані $\}$;

Мигдалини_наліт $=\{\epsilon$, немає $\}$;

Мигдалини_иілісність $=\{$ норма, виразки $\}$;

Мигдалини_zinepтрофія=\{1-го ступеня, 2-го ступеня, 3-го ступеня, 4-го ступеня $\}$;

Склери_забарвлення $=\{$ білий, жовтяничний, блакитний $\}$;

Підшкірно-жсирова_клітковина_розвиток=\{слабкий, помірний, надмірний $\}$;

Підшкірно-жирова_місия_відкладення $=\{$ живіт, руки, стегна $\}$;

Ступінь_ожиріння=\{1-а ступінь, 2-а ступінь, 3-я ступінь, 4-а ступінь $\}$;

Tun_oжсиріння $=\{$ абдомінальний, стегновий сідничний, змішаний $\}$;

Набряки_локалізація=\{кінцівки, поперек, живіт, обличчя $\}$;

Набряки_поширення $=\{$ місцеві, анасарка $\}$;

Набряки_вираженість $=\{$ пастозність, помірні, різко виражені $\}$;

Набряки_консистенція $=\{$ м'які, щільні $\}$; 
Лімфатичні_вузли_локалізація=\{потиличні, привушні, підщелепні, шийні, над- и підключичні, підпахові, ліктьові, пахові підколінні\};

Лімфатичні_вузли_величина=\{норма, збільшені $\}$;

Лімфатичні_вузли_хворобливість $=\{\epsilon$, немає $\}$;

М'язи_ступінь_розвитку $=\{$ задовільна, слабка $\}$;

М'язи_явища $=\{$ атрофія, гіпертрофія $\}$;

M'язи_тонус $=\{$ знижений, збережений, підвищений $\}$;

М'язи_хворобливість $=\{\epsilon$, немає $\}$;

Судоми $=\{$ клонічні, тонічні $\}$;

Деформація_скелета $=\{$ сколіотична постава, посилення вигинів, зменшення вигинів, лордосколіотична спина, кіфосколіотична спина $\}$;

Кістки_хворобливість_биття_обмаиування $=\{\epsilon$, немає $\}$;

Симптом_«барабанних паличок»= $\{\epsilon$, немає $\}$;

Суглоби_зміна_конфігуращіï=\{припухлість, дефігурація, деформація\};

Суглоби_mun_болю=\{механічний, запальний, функціональний $\}$;

Суглоби_уранішня_скутість $=\{\epsilon$, немає $\}$;

Суглоби_температура_шкіри_над_суглобом $=\{$ гіперемія, гіпертермія $\}$;

База нечітких правил організована у вигляді блоків правил у відповідності 3 пропедевтичним алгоритмом системного обстеження хворого лікарем-терапевтом [3]: первинні скарги пацієнта, загальний огляд пацієнта, система органів дихання, система органів кровообігу, шлунково-кишковий тракт, печінка i жовчний міхур, селезінка, підшлункова залоза, система органів сечовиділення, ендокринна система, нервова система і органи почуттів, a також блок лабораторних i інструментальних методів досліджень та блок постановки діагнозу.

Оскільки управління для кожної групи правил, які описують обстеження певної системи хворого, передається групі правил постановки діагнозу, то відбувається перетин основних груп. Проте це не призводить до суперечності бази правил, оскільки у будь-який момент часу база правил працює тільки з однією з основних груп.

База нечітких правил інтелектуальної системи діагностики захворювань містить правила у формі:

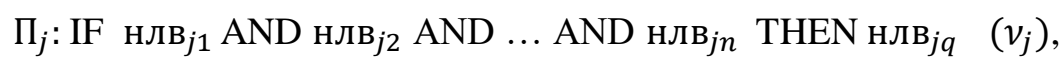

де $\left(v_{j}\right)$ - ступінь достовірності правила: 3 передумови витікає слідство; нлв $j i-$ нечітке лінгвістичне висловлювання.

У нечітких системах існує дві форми представлення правил в базі знань: зовнішнє $\mathrm{i}$ внутрішнє. Зовнішнє представлення припускає, що правило повинно бути зрозуміле фахівцю в предметній області, тобто читабельно. Внутрішнє представлення повинно бути зрозуміле механізму виведення, який використовує сенс вибраного правила, використовуючи рівняння (4).

Для зовнішнього представлення правила в (5) замість нлв ${ }_{j i}$ використовується запис:

$$
X \in \aleph
$$

де $X$ - ім'я лінгвістичної змінної, $\aleph$ - значення лінгвістичної змінної.

Для внутрішнього представлення правила використовується наступний запис (5) [2]:

$$
\operatorname{IF} R\left(X_{1}, e\right) \text { AND } R\left(X_{2}, e\right) \text { AND } \ldots \text { AND } R\left(X_{n}, e\right) \text { THEN } R\left(Y_{q}, e\right)
$$

де $R\left(X_{i}, e\right), R\left(Y_{q}, e\right)-$ нечіткі обмеження на значення вхідних и вихідних змінних.

Наведемо приклади зовнішнього представлення правил для визначення типу простудного захворювання.

ПРАВИЛО ПЗ_1: IF «Самопочуття_погіршення $\epsilon$ поступове» AND «Температура_тіла $\epsilon$ субфебрильна» AND «Інтоксикація $\epsilon$ не виражена» AND «Нос_нежить_закладеність $\epsilon$ в перші години» AND «Чхання $\epsilon$ присутнє» AND «Горло_біль $\epsilon$ слабка» AND «Очі_дискомфорт $\epsilon$ 
відсутній» AND «Головна_біль $\epsilon$ відсутня» AND «Підвищена_стомлюваність $\epsilon$ відсутня» AND «Безсоння $\epsilon$ відсутнє» THEN «Діагноз $\epsilon$ простуда»

ПРАВИЛО П3_2: IF «Самопочуття_погіршення $\epsilon$ швидке» AND «Температура_тіла $\epsilon$ субфебрильна» AND «Інтоксикація $\epsilon$ часткова» AND «Нос_нежить_закладеність $\epsilon$ в перші дні» AND «Чхання $\epsilon$ присутнє» AND «Горло_біль $\epsilon$ середня» AND «Очі_дискомфорт $\epsilon$ частково присутній» AND «Головна_біль $\epsilon$ часткова» AND «Підвищена_стомлюваність $\epsilon$ часткова» AND «Безсоння $\epsilon$ часткове» THEN «Діагноз $\epsilon$ гостра респіраторна вірусна інфекція»

ПРАВИЛО ПЗ 3: IF «Самопочуття_погіршення $\epsilon$ раптове» AND «Температура тіла $\epsilon$ висока лихоманка» AND «Інтоксикація $\epsilon$ сильна» AND «Нос_нежить_закладеність $\epsilon$ через 2-3 доби» AND «Чхання $\epsilon$ відсутнє» AND «Горло_біль $\epsilon$ сильна» AND «Очі_дискомфорт $\epsilon$ присутній» AND «Головна_біль $\epsilon$ сильна» AND «Підвищена_стомлюваність $\epsilon$ часткова» AND «Безсоння $\epsilon$ сильне» THEN «Діагноз $\epsilon$ грип»

Також наведемо приклад внутрішнього представлення правила для визначення тину простудного захворювання, де $R(x, e)$ - обмеження для лінгвістичної змінної:

ПРАВИЛО В_П3_1: IF $R$ (Самопочуття_погіршення, $e$ ) AND $R$ (Температура_тіла, $e$ ) AND $R$ (Інтоксикація, $e) \quad$ AND $\quad R$ (Нос_нежить_закладеність, $e) \quad$ AND $\quad R$ (Чхання, $e$ ) $\quad$ AND $R($ Горло_біль, $e) \quad$ AND $\quad R$ (Очі_дискомфорт, $e) \quad$ AND $\quad R($ Головна_біль, $e) \quad$ AND $R$ (Підвищена_стомлюваність, $e$ ) AND $R$ (Безсоння, $e$ ) THEN $R$ (Діагноз, $e$ )

Висновки. Основою моделі представлення експертних знань в інтелектуальній системі діагностики захворювань $є$ продукційна модель представлення знань. Ця модель вибрана, оскільки має ряд переваг: модульність, модифіковність, доступність читання, універсальність, ефективність організації пам'яті. Недоліки моделі усуваються шляхом використання лінгвістичних змінних і нечітких продукцій.

Таким чином система нечітких продукцій, що використовує знання у вигляді лінгвістичних змінних, є найбільш відповідною моделлю представлення експертних знань в інтелектуальній системі діагностики захворювань.

\section{ЛIТЕРАТУРА}

1. Штучний інтелект. - У 3-х кн. Кн. 2. Моделі і методи: Довідник; [під ред. Д.А. Поспелова]. - М.: Радіо і зв'язок, 1990: 304.

2. Каргін А. О. Введення в інтелектуальні машини. Книга 1. Інтелектуальні регулятори/ А. О. Каргін. Донецьк: Норд-Пресс, ДонНУ, 2010: 526.

3. Івашкін В. Т. Пропедевтика внутрішніх хвороб: підручник для студентів медичних вузів/ В. Т. Івашкін, А. А. Шептулін. - М.: МЕДпресс-інформ, 2005: 229. 